\title{
Completeness of Designs of Lifelong Learning Programmes: Assessment of the Level of Conception of Student Projects
}

\author{
Karel Nemejc ${ }^{1}$ Ing., Ph.D.; Lucie Smekalova ${ }^{2}$ PhDr., Ph.D. et Ph.D.; \\ Emil Kriz ${ }^{3}$ Ing., Ph.D. \\ Czech University of Life Sciences Prague, Institute of Education and Communication, \\ Czech Republic \\ $\underline{\text { nemejc@ivp.czu.cz }}{ }^{1}$ smekaloval@ivp.czu.cz ${ }^{2} ; \underline{\text { kriz@ivp.czu.cz }}{ }^{3}$
}

\begin{abstract}
Nowadays, designing and implementing projects in practice is one of the basic prerequisites of a university graduate. In the field of education, a project can also be related to the creation of training programmes. It is essential for planning any programme to consider a range of different factors such as concept of the activity, schedule, budget, staffing, ways of implementation, space possibilities, and others. The Institute of Education and Communication is a pedagogical and scientific research institute of the Czech University of Life Sciences Prague, which systematically focuses among other things on the development of professional competencies of students through the implementation of their professional practice and pedagogical practice. The Institute is also engaged in the education of future counsellors in the sector of vocational education (namely a Bachelor field of study "Guidance in Vocational Education"). It is these students who should be able to analyse the educational needs of the given situation or entity and to create an educational programme with respect to all the necessary steps and stages to reach its successful implementation. The aim of the study is to analyse the assessment reviews of student projects consisting of the design of their own lifelong learning programme and to evaluate the level of conception and completeness of these student project designs, where the students are to demonstrate the ability of the synthetically-analytical thinking and application of the principles of vocational education. A total of 170 evaluation reviews of designed Bachelor student projects in fulltime and part-time forms of study were under investigation. The reviews from three academic years in a row, namely 2013-2014, 2014-2015, 2015-2016, were analysed in terms of the value of ratings of selected items given within the appropriate scale. It was concluded that students of the last years of Bachelor degree programmes, both full-time and part-time groups, were able to project education programmes of varying scope and for different target groups. Students of the part-time form of study were better assessed than full-time students.
\end{abstract}

Keywords: Project, conception, lifelong learning, assessment, vocational education.

\section{Introduction}

Designing and implementing projects in practice is one of the basic prerequisites of a university graduate. In general, the concept of a project can be viewed from different perspectives. A project can be referred to as a processed intention, timetable or plan of any future activity or its outcome (a building, a machine, and the like). The creation of such projects is called designing and the person who is involved is the designer. In addition, a project can be seen as a time-bound effort that aims to create a unique product or service involving more people linked to the project team for the duration of the project. Such an effort can be characterized by a three-dimensional objective (project scope, schedule and costs). This is the area of so-called project management (Fox, Van der Waldt, 2008; Rosenau, Githens, 2005). For the latter definition, in education a project can also be related to the creation of training programmes, teaching materials or to planning further education, including all the necessary stages of their implementation (Heyworth, 2002; Lucas, Spencer, Claxton, 2012). According to G. Thomas (2013), in the field of education, a project is an individual or collaborative activity that is carefully planned and explored by students. In educational institutions, the project is a research task for the student generally requiring more effort and more independent work than common assignments. This means that it is necessary to pay attention to the project initiation, analysis and planning, findings, conclusions and closure of the project (Heyworth, 2002; Rosenau, Githens, 2005).

Focusing on lifelong learning J. Yang, C. Schneller and S. Roche (2015) mention that it is becoming a part of education policy discourse around the globe. It is the process, which supports the lifelong learning of each citizen. In our country, according to The Strategy of Lifelong Learning in the Czech Republic (Ministry of Education..., 2007) the basic precondition for achieving success in a modern, 
dynamically developing economic environment lies particularly in the ability of the inhabitants of this country to compete in the global, rapidly changing labour market. Lifelong learning includes formal education, which is performed in educational institutions, usually in schools. Its functions, targets, contents, organizational forms and methods of assessment are defined by legal regulations. This encompasses obtaining the given level of education (primary, secondary, tertiary education). Nonformal education is less formal in terms of its performance criteria and is more concerned with daily life problems. It emphasizes gaining knowledge, skills and competencies that can improve the social and working position of the individual. Non-formal education is provided by employers, private educational institutes, schools and other organizations. These include organized leisure time activities for participants of different ages such as foreign language courses, computer courses, retraining courses and also short-term training and lectures. This kind of education requires the participation of a professional instructor, teacher or trained organizer. It does not lead to obtaining a level of education. The last one, informal learning, which is understood as a process of obtaining knowledge, acquiring skills and competencies from everyday experience and activities at work, in the family and in one's leisure time. It also includes self-education, where the learner has no way of testing their acquired knowledge (MedelAnonuevo, 2002; Ministry of Education..., 2007; Petty, 2009; Van Merrienboer et al., 2009).

Lifelong learning programmes should be designed in such a way as to provide progression to a level higher than that of learners' prior achievement, they should include qualifications that are of sufficient size and accurate to stretch learners and are clearly linked to suitable progression opportunities in training, employment or higher levels of education. Such programmes should include focus on qualifications such as functional skills that will act as a stepping stone for learners' achievement, they should allow for meaningful work experience related to the vocational area of the study programme, which develops employability skills and/or creates potential employment options. Educational institutions and their tutors are likely to be involved with the planning of their own study programme. It is crucial for planning a programme to consider a range of different factors, including the following: (a) the learners, what their needs are - learning objectives, (b) what classrooms/facilities are available, (c) teaching models and strategies, (d) the use of teaching skills and what support is available to enhance the learning process, (e) a timescale - what the timescales are - what the key dates for induction, assessment and evaluation are, (f) ways of engagement and motivation of the learners, (g) ways of assessment of learners' progress and achievement, the application of their developing knowledge and understanding (Ingle, Duckworth, 2013). In a nutshell, key considerations of designing an educational programme should consist in particular of a curriculum and its components in individual courses, timetable, staffing, space for realization of the programme, costs of implementation of the educational programme, learning objectives, forms and methods of teaching, activities of educators and learners, key learning resources and support of teaching and learning process, criteria and methods of formative and summative assessment of the learners and for evaluation of the programme (Bakay, Kalem, Slavík, 2010; European Commission, 2015; Petty, 2009).

A significant part of study programmes should consist of acquiring professional experience and linking the acquired knowledge with the application in practice. Following the above-mentioned context, the Institute of Education and Communication is a pedagogical and scientific research institute of the Czech University of Life Sciences Prague, which systematically focuses among other things on the development of professional competencies of students through the implementation of their professional practice and pedagogical practice, as mentioned by E. Kriz (2014). Besides students of Bachelor fields of study with specialization in teaching of vocational subjects and practical training, the Institute is also engaged in the education of future counsellors in the sector of vocational education (a Bachelor field of study "Guidance in Vocational Education"). It is these students who should be able to analyze the educational needs of the given situation or entity and to create an educational programme, most often in non-formal education, including all its steps and stages of its successful implementation. In reality, these students are acquainted among other activities with the issues of project management, with the design of educational programmes, evaluation tools for assessing educational programmes, principles of management in education, and so on. In the last year of their studies, the students are assigned to respect the given instructions to project a comprehensive design of a lifelong learning programme for the chosen discipline and target group, including organizational and economic aspects and recommendations of tools for its evaluation. These projects are developed in conjunction with the professional practice of the students in educational institutions, organizations, companies where corporate training takes place, and 
so on. Each of the projects is designed, defended for a commission of professionals and for the audience at the annual institutional student conference and evaluated both by the assigned evaluator and by the commission in order to determine whether it meets the specified criteria and whether it would be applicable in practice. In this way, students demonstrate that they are acquainted with the methodology of designing educational programmes for vocational education and training, that they are able to apply their knowledge to independent work and teamwork, and that they are well prepared for effective communication with clients, especially in the field of professional and educational counselling. They further demonstrate that they will be able to co-ordinate the work of others, lead workgroups, that they have competencies to think systematically and critically, and that they will be able to make comprehensive assessments of situations and problems.

The aim of the study is to analyse the assessments of student projects consisting of the design of their own lifelong learning programme and to evaluate the level of conception and completeness of these student project designs.

\section{Methodology}

As indicated above, the aim of the field of study "Guidance in Vocational Education" is to provide graduates with competencies to perform professional and managerial activities in the sector of further vocational education and training. The graduates acquire professional competencies that enable them to create and evaluate educational programmes and actively implement their own vocational education process. Theoretical knowledge and practice in lectures and seminars are closely linked to professional practice of the students of the last year of study at the selected workplace. Linking their theoretical basis and practical experience the students think of the project of non-formal education and design a complex programme in the field of lifelong learning. The project of further education is based primarily on the needs and conditions of the workplace for performing the practice. Such a student project is designed independently under the responsibility of the supervisor of the workplace and it solves the needs of the workplace. As stated in the introductory part, each of the students designs such a comprehensive project, defends it for a commission of professionals and for the audience at the annual institutional student conference and is given an assessment of the project processed by the assigned evaluator and by the commission, all being members of the academic staff of the Institute, in order to determine whether it meets the specified criteria and whether it would really be applicable in practice. In the presented project, the student is to demonstrate the ability of the synthetically-analytical thinking and application of the principles of vocational education.

The researchers are academic staff of the Institute for Education and Communication as well, and they are also involved in the assessment of student projects related to practice. They were interested in the analysis of the review assessments of student projects consisting of the design of their own lifelong learning programme. Furthermore, the purpose of their investigation was to evaluate the level of conception and completeness of these student project designs.

Project reviews consisted of assessing the following aspects based on given criteria, as described e.g. by W. Fox and G. Van der Waldt (2008), S. Ingle and V. Duckworth (2013), G. Petty (2009), and M.D. Rosenau and G.D. Githens (2005) in the introductory part of the paper:

- the contribution of the project (programme) for practice,

- the level of language and professional processing of the project,

- the formal level of the project.

In the end, the reviewer assigns an overall assessment of the concept of the student project. The assessment of these categories was distributed on a rating scale ranging from one (the best design of the project) to four (the worst design of the project). Further analysis of empirical data was performed based on their division into two groups. In particular, the data were treated as a sum of the best and worst values in a $1: 1$ ratio $(50 \%: 50 \%)$.

Evaluation reviews of student projects from three academic years in a row, namely 2013-2014, 2014-2015, 2015-2016, were analysed in terms of the value of ratings given within the appropriate scale. This continuity is important because it follows the same set of conditions for the project, it means the same assignment to all students, the same curriculum, and the same personnel assurance by academic staff. A total of 170 designed student projects of third-year students of the field of study "Guidance in 
Vocational Education", both in full-time $(\mathrm{N}=95)$ and part-time forms of study $(\mathrm{N}=75)$ were under investigation.

Comparison of the results (total average values) is therefore appropriate in terms of the comparable number of respondents in the three individual years in both full-time and part-time forms of study.

The results of analyses are presented in the following section.

\section{Results and Discussion}

A total of 170 projects assessment reviews were analysed. Overall, nine pairs of assessed items, so three items per each of the three academic years and per the form of study, were compared. The items were as follows: the contribution of the project / programme for practice, the level of language and professional processing of the project, and the formal level of the project were compared. Furthermore, an assessment of these three items was made in the sense of the overall assessment of the concept of the student project (Table 1).

Table 1

Average values of assessment of the level of conception and completeness of student projects

\begin{tabular}{|c|c|c|c|c|c|c|c|}
\hline $\begin{array}{c}\text { Form of } \\
\text { study }\end{array}$ & $\begin{array}{c}\text { Academic } \\
\text { year }\end{array}$ & $\begin{array}{c}\text { Number of } \\
\text { project } \\
\text { assessment } \\
\text { reviews }\end{array}$ & $\begin{array}{c}\text { Contribution } \\
\text { of the project } \\
\text { /programme } \\
\text { for practice }\end{array}$ & $\begin{array}{c}\text { Level of } \\
\text { language } \\
\text { and } \\
\text { professional } \\
\text { processing }\end{array}$ & $\begin{array}{c}\text { Formal } \\
\text { level of } \\
\text { the } \\
\text { project }\end{array}$ & $\begin{array}{c}\text { Overall } \\
\text { assessment of } \\
\text { the concept of } \\
\text { the student } \\
\text { project }\end{array}$ \\
\cline { 4 - 7 } & & \multicolumn{2}{|c|}{ (1-the best, 4-the worst design of the project) } \\
\hline $\begin{array}{c}\text { Full-time } \\
\text { students }\end{array}$ & $\begin{array}{c}2013- \\
2014\end{array}$ & 27 & 1.41 & 1.44 & 1.59 & 1.48 \\
\hline $\begin{array}{c}\text { Part-time } \\
\text { students }\end{array}$ & $\begin{array}{c}2013- \\
2014\end{array}$ & 29 & 1.38 & 1.41 & 1.52 & 1.44 \\
\hline $\begin{array}{c}\text { Full-time } \\
\text { students }\end{array}$ & $\begin{array}{c}2014- \\
2015\end{array}$ & 39 & 1.38 & 1.59 & 1.64 & 1.54 \\
\hline $\begin{array}{c}\text { Part-time } \\
\text { students }\end{array}$ & $2014-$ & 2015 & 23 & 1.35 & 1.43 & 1.65 & 1.48 \\
\hline $\begin{array}{c}\text { Full-time } \\
\text { students }\end{array}$ & $\begin{array}{c}2015- \\
2016\end{array}$ & 29 & 1.66 & 1.55 & 1.69 & 1.63 \\
\hline $\begin{array}{c}\text { Part-time } \\
\text { students }\end{array}$ & $2015-$ & 2016 & 23 & 1.29 & 1.42 & 1.29 & 1.33 \\
\hline
\end{tabular}

It was found out in the analysis of the three items concerned that besides a comparison that was identical for both full-time and part-time students (the contribution of the project / programme for practice), parttime students were better assessed than full-time students. This means that in most cases, namely in 6 comparisons out of 8 (i.e. $75 \%$ ), the part-time students have better competencies to design the project.

The item analysing the contribution of the project/programme for practice clearly demonstrates the greater experience of part-time students because their projects were often tailored to the environment in which the students work. Full-time students do not have this experience, or they have it but to a much lesser extent, therefore their projects appear to be a practicing of the design of the project rather than a practical implementation of the project in the real life. Overall, however, it can be argued that in the vast majority of cases, this item reached the best evaluation of all the observed items. This may be because the project is based on practice and at the same time the practice can be influenced by such projects. It is positive that students perceive the sense of practice and see the connection of theoretical knowledge in practice.

The item related to the level of language and professional processing of the project is again related to the experience of the respondents of the part-time form of study. It can therefore be argued that those students use specific vocational and technical terms commonly in their practice and that they have a better fixation of their use. Language processing is also reflected in broader vocabulary, as the process of communication in a corporate environment of their workplaces provides a greater likelihood of the use of such a language. On the contrary, full-time students have fewer vocabulary and communication 
capabilities that are directly related to project management. The differences between the two groups of respondents (full-time and part-time students) are not very significant (several tenths only), but they are traceable in the results of individual evaluations.

When analyzing the assessments (average values) of the item dealing with the formal level of the project, the part-time students again achieved (with the exception of one academic year) better results compared to full-time students. Although this item may also be affected by respondents' time options, i.e. by the lack of time to respect the rules of the formal design of the project. On the other hand, students in the part-time form of study showed a higher responsibility for assigning the design of the project according to the given instructions. The results of differences between the two groups are therefore not clear in the sense of which group has what causes that led to these results. In other words, this item shows that there may be a lot of causes and it cannot be clearly determined that it is the impact of part-time or full-time studies. The results often depend also on the nature of the respondent and on their approach to studies.

In addition, when looking at the overall assessment of the concept of the student project it is evident that students of part-time studies in all three examined academic years achieved better results than students of full-time study programmes, although the average values between these groups differ only in the order of tenths.

\section{Conclusions}

The aim of the Bachelor field of study "Guidance in Vocational Education" of the Institute of Education and Communication of the Czech University of Life Sciences Prague is to develop the competencies of the graduates to perform their professional and managerial activities in the field of lifelong and further vocational education.

- In any case, when analysing items of review assessments of student projects examining completeness of designs of lifelong learning programmes it has been shown that students of the last years of Bachelor degree programmes are able to project education programmes of varying scope and for different target groups.

- Furthermore, it has been demonstrated for the three-year observed period, regardless of examining possible causes, that the students of part-time forms of study achieved better results in projecting designs of lifelong learning programmes compared to the groups of students of the full-time studies. As significant and anticipated can be considered mainly the item of the contribution of the project (programme) for practice.

- The item of the contribution of the project (programme) for practice can be considered as the best one when looking at the overall results.

- On the basis of the average values of each of the monitored items, the authors were convinced of the importance of the courses that are the part of the study programme concerned and of the benefits of professional practice in the last stage of study, where the students acquire new experience and, on the other hand, they can apply their theoretical knowledge, skills and professional competencies.

- However, in the future, it will be necessary to analyse the presented student projects in qualitative terms, focusing on the content of the projects and on the particular deficiencies that students make in the design of their projects.

\section{Bibliography}

1. Bakay E.M., Kalem G., Slavík M. (Eds.). (2010). Project Based School Management: Training Modules for Managers and Other Managerial Staff. Izmir, Turkey: Menderes Town National Education Directorate.

2. European Commission. (2015). ECTS Users' Guide 2015. Luxembourg: Publications Office of the European Union. Retrieved from https://ec.europa.eu/education/ects/users-guide/docs/ects-usersguide en.pdf

3. Fox W., Van der Waldt G. (2008). A Guide to Project Management. Cape Town: Juta Academic. 
4. Heyworth F. (2002). A Guide to Project Management. Graz, Austria: European Centre for Modern Languages. Retrieved from http://archive.ecml.at/documents/pub141e2002.pdf

5. Ingle S., Duckworth V. (2013). Teaching and Training Vocational Learner. London: Learning Matters.

6. Kriz E. (2014). Training Teacher at Pedagogical Practice of Students - The Partner of Academic Teacher. In V. Dislere (Ed.), The Proceedings of the International Scientific Conference Rural Environment. Education. Personality, 7. Jelgava, LLU, TF, 187-191.

7. Lucas B., Spencer E., Claxton G. (2012). How to Teach Vocational Education: A Theory of Vocational Pedagogy. London: City and Guilds Centre for Skills Development.

8. Medel-Anonuevo C. (Ed.). (2002). Integrating Lifelong Learning Perspectives. Manila: UNESCO Institute for Education.

9. Ministry of Education, Youth and Sports. (2007). The Strategy of Lifelong Learning in the Czech Republic. Prague: Ministry of Education, Youth and Sports. Retrieved from http://www.msmt.cz/uploads/Zalezitosti_EU/strategie 2007 EN web jednostrany.pdf

10. Petty G. (2009). Teaching Today: A Practical Guide. $\left(4^{\text {th }}\right.$ ed.). Cheltenham: Nelson Thornes.

11. Rosenau M.D., Githens G.D. (2005). Successful Project Management: A Step-by-Step Approach with Practical Examples. (4 ${ }^{\text {th }}$ ed.). Hoboken, NJ: John Wiley and Sons Inc.

12. Thomas G. (2013). How to Do Your Research Project: A Guide for Students in Education and Applied Social Sciences. ( $2^{\text {nd }}$ ed.). London: Sage Publications Ltd.

13. Van Merrienboer J., Kirschner P.A., Paas F., Sloep P.B., Caniels M. (2009). Towards an Integrated Approach for Research on Lifelong Learning. Educational Technology Magazine: The Magazine for Managers of Change in Education, 49(3), 3-15. Retrieved from https://hal.archivesouvertes.fr/hal-00696399/document

14. Yang J., Schneller C., Roche S. (Eds.). (2015). The Role of Higher Education in Promoting Lifelong Learning. Hamburg: UNESCO Institute for Lifelong Learning. Retrieved from http://unesdoc.unesco.org/images/0023/002335/233592e.pdf 